\title{
Use of human protein $C$ concentrates in the treatment of patients with severe congenital protein $C$ deficiency
}

This article was published in the following Dove Press journal:

Biologics: Targets \& Therapy

6 March 2010

Number of times this article has been viewed

\author{
Sabine Kroiss \\ Manuela Albisetti \\ Division of Hematology, University \\ Children's Hospital, Zurich, \\ Switzerland
}

\begin{abstract}
Protein $\mathrm{C}$ is one of the major inhibitors of the coagulation system that downregulate thrombin generation. Severe congenital protein $\mathrm{C}$ deficiency leads to a hypercoagulability state that usually presents at birth with purpura fulminans and/or severe venous and arterial thrombosis. Recurrent thrombotic events are commonly seen. From the 1990's, several virus-inactivated human protein $\mathrm{C}$ concentrates have been developed. These concentrates currently constitute the therapy of choice for the treatment and prevention of clinical manifestations of severe congenital protein $\mathrm{C}$ deficiency. This review summarizes the available information on the use of human protein $\mathrm{C}$ concentrates in patients with severe congenital protein $\mathrm{C}$ deficiency.

Keywords: Congenital protein $\mathrm{C}$ deficiency, protein $\mathrm{C}$ concentrate, purpura fulminans
\end{abstract}

\section{Introduction}

Protein $\mathrm{C}(\mathrm{PC})$ is a vitamin K-dependent coagulation inhibitor produced by hepatocytes. Plasma PC circulates as a 62-kDa-precursor serine protease that is activated by thrombin bound to a specific membrane protein, thrombomodulin. Together with its cofactor, protein S, activated PC specifically inhibits factor (F) Va and FVIIIa in a calcium and phospholipid-dependent manner, which in turn downregulates thrombin generation. Similar to all other vitamin K-dependent coagulation proteins, plasma concentration of circulating PC is significantly decreased at birth and during childhood at approximately $50 \%$ and $20 \%$ of adult values, respectively. This age-dependent decreased plasma concentration of PC is physiological and does not increase the thrombotic risk during childhood. ${ }^{1}$

Congenital PC deficiency is an autosomal dominant inherited disorder caused by mutations of the PC gene (PROC, OMIM \#176860) located on chromosome 2q13-14. Thus far, 151 different mutations have been described. ${ }^{2}$ Reported incidence of heterozygous PC deficiency varies between 1 in 200 to 1 in 500 healthy individuals. The incidence of homozygous PC deficiency is estimated at 1 in 500 000-750 000 of newborns, with an equal distribution between males and females. ${ }^{3}$

Congenital PC deficiency is associated with an increased risk of thromboembolic events. While heterozygous PC deficiency in adult patients is associated with a 10 -fold increased risk of developing thromboembolic events compared to the general population, homozygous or double heterozygous PC deficiency represents a severe thromboembolic disorder. This usually manifests within hours of birth with life-threatening purpura fulminans (PF) and large-vessel thrombosis requiring urgent therapy including PC substitution. ${ }^{4}$

Until the end of the 1980's, no human PC concentrates were available. Patients with severe PC deficiency were treated with infusions of fresh frozen plasma (FFP) or 
cryoprecipitate. ${ }^{5-12}$ Many of these patients died. ${ }^{6,13}$ Following the introduction of commercially available human PC concentrates, several patients have been successfully treated and their cases are reported in the literature. ${ }^{14}$

This review will summarize the available information on the use of human PC concentrates to treat severe congenital $\mathrm{PC}$ deficiency.

\section{Severe congenital protein $\mathbf{C}$ deficiency Clinical presentation}

While intrauterine and prenatal presentation (including arterial ischemic stroke and cerebral hemorrhage, thrombosis of the vitreal veins, and retinal arterial thrombosis and hemorrhage) has been reported, severe congenital PC deficiency usually presents immediately after birth with life-threatening PF and/or disseminated intravascular coagulation (DIC)., ${ }^{3,59,12}$ Purpura fulminans is an acute, progressive hemorrhagic necrosis of the skin caused by dermal vascular thrombosis. Lesions present initially as small ecchymoses that rapidly become purplish black with bullae, and then become necrotic and gangrenous. ${ }^{15-16}$ Purpura fulminans may develop on the extremities, the buttocks, abdomen, scrotum, and scalp as well as at pressure points, previous punctures locations, and at previously affected sites. ${ }^{4}$ Following the neonatal period, severe PC deficiency may cause further episodes of PF triggered by infection or trauma and recurrent venous thrombotic events including deep vein thrombosis (DVT) and pulmonary embolism (PE) ${ }^{5,13}$

In patients with homozygous PC deficiency but small detectable levels of PC, delayed clinical presentation including spontaneous large vessel thrombosis and skin necrosis following initiation of oral anticoagulation (OAC) therapy with a vitamin $\mathrm{K}$ antagonist is usually observed. ${ }^{3,17-21}$

\section{Overview of treatment options}

Treatment options for severe congenital PC deficiency include the substitution of PC or liver transplantation. In the early 1980's, PC was replaced by the administration of FFP and/or cryoprecipitate. ${ }^{5-9}$ FFP consists of plasma separated from red cells and platelets by centrifugation of whole blood and frozen to $-18^{\circ} \mathrm{C}$ within 6 hours of collection. One milliliter of FFP contains approximately one international unit of each of the coagulation factors and inhibitors. Cryoprecipitate is the precipitated plasma protein resulting from FFP thawed at $4^{\circ} \mathrm{C}$, re-suspended in a minimal volume of residual supernatant plasma and subsequently refrozen at $-18^{\circ} \mathrm{C}$ or lower. One bag of cryoprecipitate contains approximately $100 \mathrm{U}$ of factor VIII, $880 \mathrm{U}$ of von Willebrand factor, $250 \mathrm{mg}$ of fibrinogen, and 50
$\mathrm{U}$ of factor XIII. Both concentrates require frequent plasma infusions once to twice daily to achieve significant improvement of symptoms, possibly leading to volume overload. ${ }^{12-14}$ As well, both plasma products are associated with severe adverse effects. ${ }^{5,6,9,13,22}$ Apart from the risk of infection, undesirable effects of FFP include allergic reactions, alloimmunization from contaminant red cells, and on rare occasions, pulmonary edema. ${ }^{12,23-26} \mathrm{~A}$ major side effect of cryoprecipitate is passive transfer of isoagglutinins from the ABO blood group system due to the presence of plasma immunoglobulins.

Factor IX concentrate and PC-rich prothrombin-complex concentrate (PCC) have been successfully used in patients with severe congenital PC deficiency. ${ }^{10-12}$ The concentration of PC in PCC showed an up to 10-fold variation in several brands, leading to a rise in plasma level of PC above 100 IU/dL with an approximately 7.4-hour half-life.

Following the development of human PC concentrates based on knowledge gained from the production of PCC in the 1970's, several virus-inactivated PC concentrates were developed in the 1990's. These currently constitute the treatment of choice for severe congenital PC deficiency. While a recombinant-activated PC concentrate (drotrecogin alfa, Xigris $\left.^{\circledR}\right)$ has been successfully administered on different occasions to treat episodes of PF in patients with severe congenital PC deficiency, the concern about an increased risk of major bleeding episodes in children may limit the use of this concentrate, at least in the pediatric population. ${ }^{27-31}$

A curative therapy for severe congenital PC deficiency is liver transplantation. Four patients who have undergone successful liver transplants have been reported so far. One child at 20 months and another at 6 months of age received elective living donor liver transplantation. ${ }^{32-33}$ Angelis et al reported an additional girl, who received auxiliary liver and renal transplantation due to renal insufficiency following neonatal bilateral renal vein thrombosis. ${ }^{34}$ The fourth successful liver transplant was reported in a 5-year-old boy who had previously been treated with long-term PC replacement therapy. ${ }^{35}$ In all patients, PC activity was fully reconstituted.

\section{Human protein $\mathrm{C}$ concentrates Development of human protein $\mathrm{C}$}

\section{concentrates}

The first production of human PC concentrates was based on the expertise gained from the production of PCC of Immuno AG in Vienna, Austria in the 1970's. The human PC concentrate, Ceprotin ${ }^{\circledR}$, was developed in 1990 and first put on the market by Baxter Healthcare Corporation (Deerfield, IL, USA) in 1991. Ceprotin ${ }^{\circledR}$ was licensed in 
Europe by the European Medicines Evaluation Agency in 2001 for patients with congenital PC deficiency and with complications of therapy with vitamin $\mathrm{K}$ antagonists. FDA approval of Ceprotin ${ }^{\circledR}$ for severe congenital PC deficiency was obtained in 2007 (orphan drug status). The French human plasma-derived concentrate Protexel ${ }^{\circledR}$ (LFB, France) has been available since 1994.

\section{Manufacturing of human protein $\mathrm{C}$ concentrates}

As mentioned, two human PC concentrates are available for the treatment of severe congenital PC deficiency in Europe and North America: the human plasma preparation Ceprotin ${ }^{\circledR}$ (Baxter) and the French PC concentrate Protexel ${ }^{\circledR}$ (LFB, Les Ulis, France). Another, hence-activated human PC concentrate, Anact $^{\circledR}$ (Kaketsuken, Kumamoto, Japan), is only available in Japan.

Ceprotin $^{\circledR}$ is a sterile lyophilized human PC concentrate produced from frozen human plasma, collected in the United States or Europe. The cryoprecipitate is separated and the prothrombin-complex is isolated by DEAE-Sephadex, leading to a fraction of plasma, rich in factor VII, factor IX, protein S and PC. The product undergoes several washing steps using anion exchange chromatography and immunoaffinity chromatography on a murine monoclonal antibody against human PC. Two virus inactivation steps are performed by polysorbat 80 treatments and vapor heating $\left(60^{\circ} \mathrm{C}\right.$ for 10 hours and $80^{\circ} \mathrm{C}$ for 1 hour). Human albumin is added as a stabilizer before sterile filtration. The concentrate is negatively tested for HIV, hepatitis A, B, C and parvovirus B19. Activated $\mathrm{PC}$ and murine $\mathrm{IgG}$ are not detectable. Ceprotin ${ }^{\circledR}$ contains heparin and, potentially, mouse protein. The content of more than $200 \mathrm{mg}$ sodium in daily maximum dosing has to be taken into account in patients with renal insufficiency. Both human PC concentrates contain the inactive $\mathrm{PC}$ zymogen, which is activated after infusion and allows controlling of PF and DIC in PC-deficient patients. The Ceprotin ${ }^{\circledR}$ solution has a specific PC activity of more than $200 \mathrm{IU} / \mathrm{mg}$ protein and can be administered directly as intravenous infusion. The administration of 1 IU human PC concentrate Ceprotin ${ }^{\circledR}$ leads to a median increase of plasma PC activity of $1.4 \%$. Half-life is individually variable between 4.4 and 15.9 hours (median 10 to 12 hours). During acute PF or DIC, half-life can vary significantly due to ongoing consumption. Individual recovery also shows a wide range of $20.4 \%$ to $83.2 \%$ (median 68.5\%). ${ }^{36}$
Protexel $^{\circledR}$ is produced from human plasma donations by cryoprecipitation and undergoes three anion exchange chromatography and affinity chromatography purification steps. Virus inactivation steps are performed with $1 \%$ polysorbat 80 and $0.3 \%$ tri(N-butyl)phosphate, which effectively inactivates enveloped viruses. Protexel ${ }^{\circledR}$ yields a specific PC activity of more than $100 \mathrm{IU} / \mathrm{mg}$ total protein. Half-life ranges from 7.8 to 11 hours in adults in a stable situation, dependent on the acuity of the disease. Recovery is $1.58 \%$ (range 0.8 to $1.91 \%$ ) per IU/kg injected.

Anact $^{\circledR}$ is produced from human plasma collected from unpaid donors in Japan and activated by human thrombin, followed by further washing steps with ion exchange chromatography and monoclonal antibody separation as described by Katsuura. ${ }^{37}$ Virus inactivation is performed by dry heat at $65^{\circ} \mathrm{C}$ for 10 hours and $15 \mathrm{~nm}$ nanofiltration. This concentrate is only available in Japan. Since there are only two case reports on the use of this activated human PC concentrate in the English literature, this concentrate will not be discussed further. ${ }^{38-39}$

\section{Clinical use of human protein $C$ concentrates}

Reported cases on the clinical use of PC concentrates in patients with severe congenital PC deficiency are summarized in Table 1. Human PC concentrates have been successfully used for the treatment of acute PF, DIC, DVT, and coumarin-induced skin necrosis, as well as for prophylaxis to avoid relapse of acute symptoms, in the initial phase of $\mathrm{OAC}$ therapy, and during surgical procedures.

\section{Use in acute clinical situations}

Reports of 62 patients treated with human PC concentrate are available (Table 1). Forty patients were treated for typical neonatal manifestation, specifically PF in 36 of them. Intracerebral hemorrhage or infarction was present in 13 patients and eye complications, ie, vitreous hemorrhage and retinal arterial thrombosis and hemorrhage were present in 26 patients. Seven patients presented with coumarin-induced episodes of skin necrosis, three of them were adult patients, and four were children aged 8 to 16 years. Two patients were treated because of DVT. Only patients reported by Dreyfus et $\mathrm{al}^{23}$ were treated with Protexel ${ }^{\circledR}$, all other patients received Ceprotin ${ }^{\circledR}$ or the corresponding former PC concentrate, developed by Immuno AG, Vienna. ${ }^{14,17-21,33,35,40-68}$

In the vast majority of cases, treatment was initiated by replacement of FFP at doses of 10 to $15 \mathrm{~mL} / \mathrm{kg}$ every 


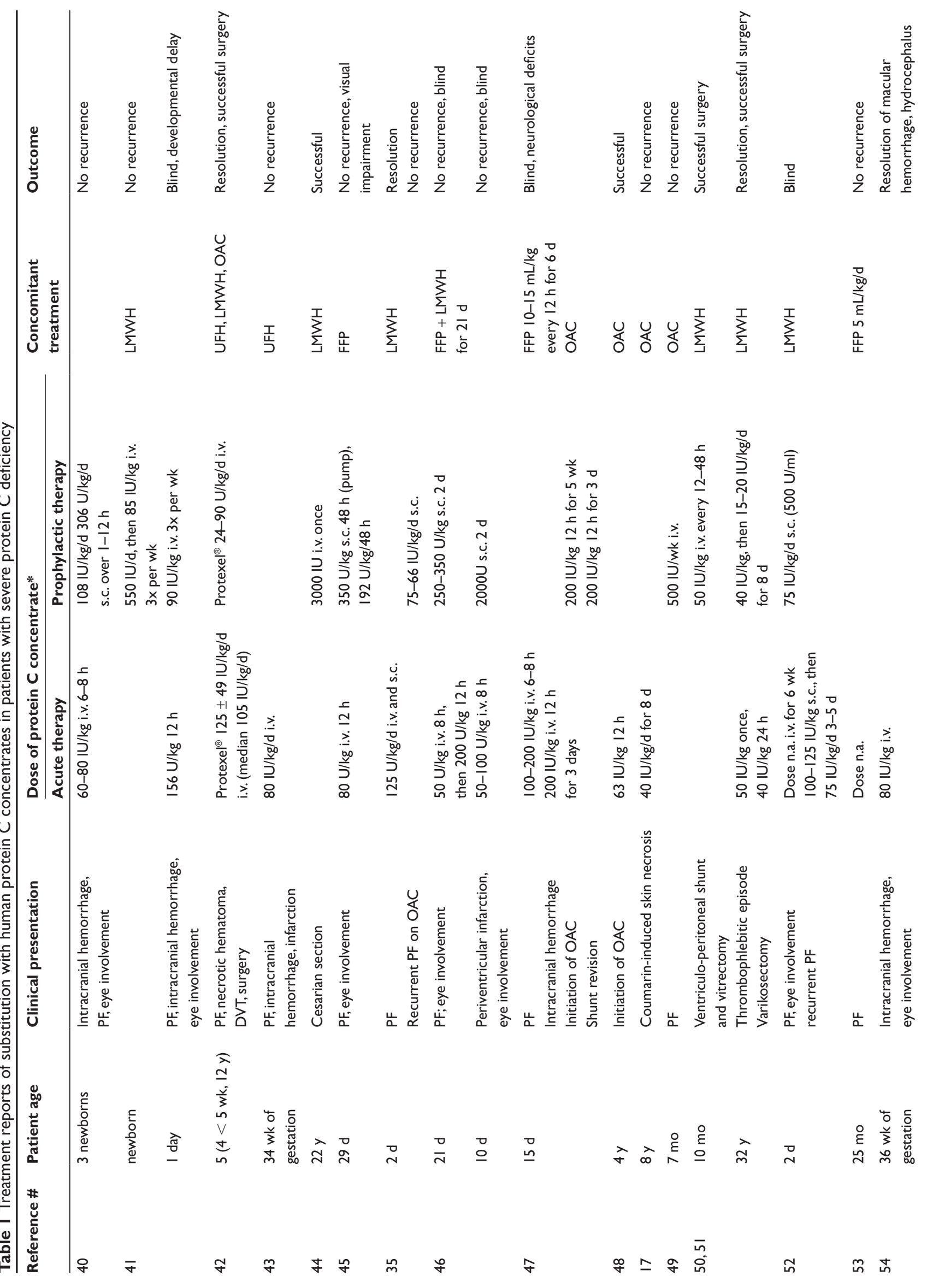



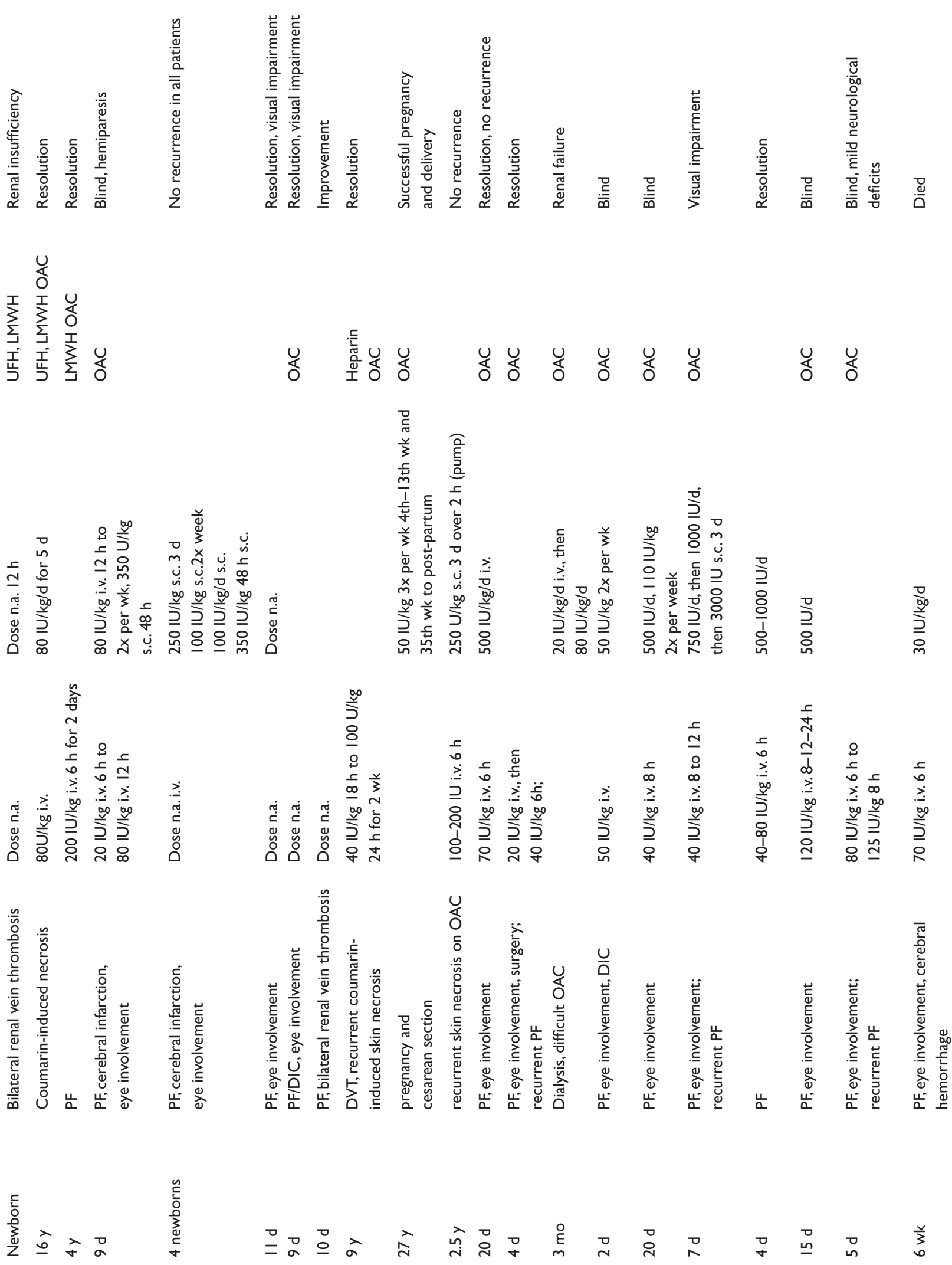

$\stackrel{0}{=} \underset{0}{0} \stackrel{0}{a} \stackrel{\lambda}{\lambda}$

^ิ

西

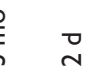

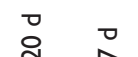

ช

$\underset{3}{\stackrel{2}{3}}$

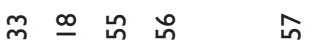

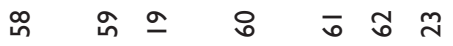




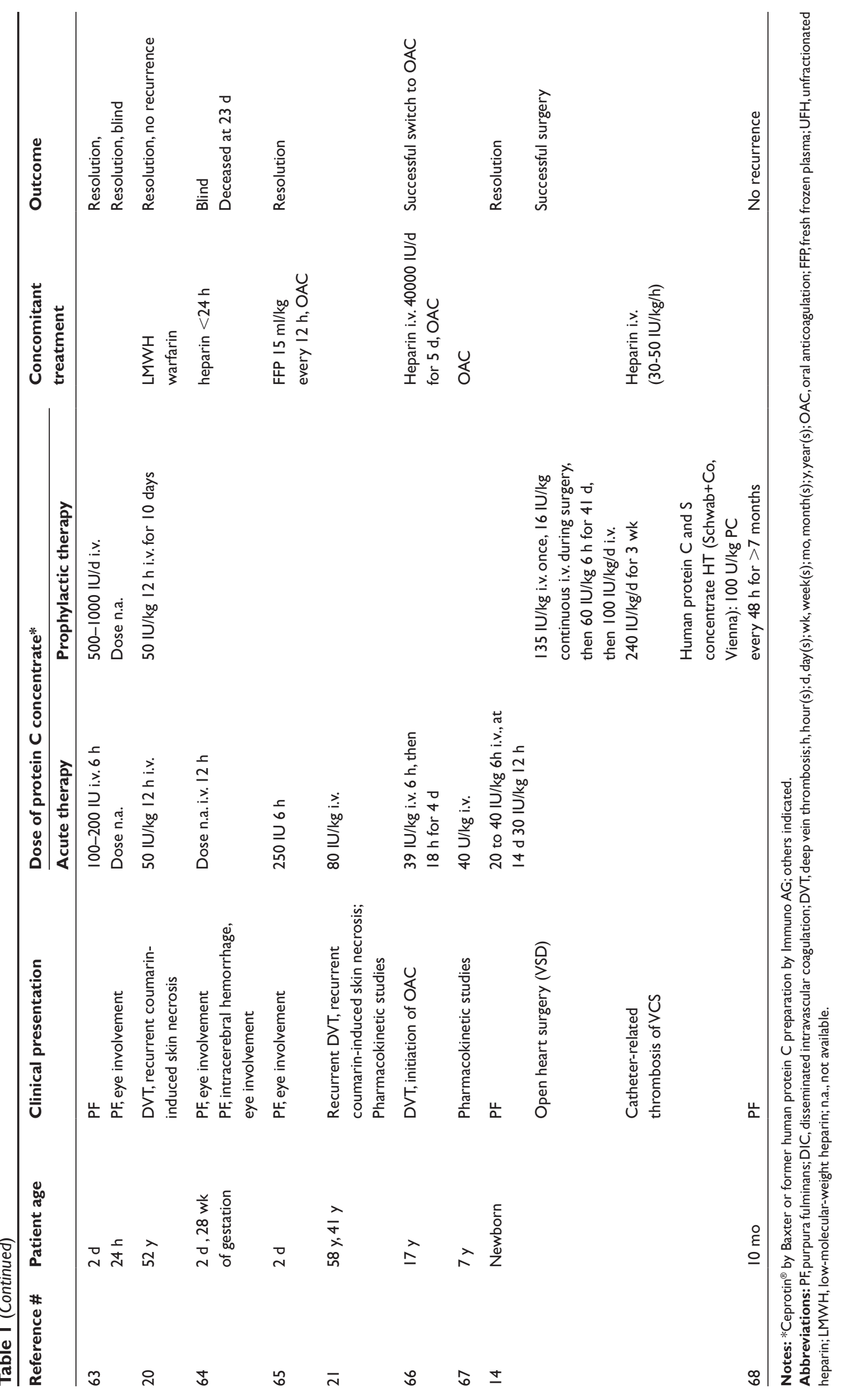


6 to 12 hours (next to heparin, cryoprecipitate, tissue plasminogen activator and others), followed by substitution of human PC concentrate, as soon as diagnosis of severe PC deficiency was made and/or the product was available. To treat PF or DIC, the daily dose of human PC concentrate varied between $80 \mathrm{IU} / \mathrm{kg}$ in a single daily dose and $750 \mathrm{IU} /$ $\mathrm{kg}$ in repeated doses (250 IU/kg every 6 hours) depending on the degree and resolution of clinical symptoms during treatment. In most cases the dosage of PC concentrate was titrated according to target PC activity levels of $100 \%$ and trough levels of $25 \%$, or was adapted according to clinical stabilization, usually occurring after several days to weeks. Recurrent episodes of PF during OAC with vitamin K antagonists were treated with PC concentrate. Dosage of PC concentrate in these occasions ranged from $80 \mathrm{IU} / \mathrm{kg}$ once daily to $100-125 \mathrm{IU} / \mathrm{kg}$ as a first dose followed by repeated doses of $75 \mathrm{IU} / \mathrm{kg}$ to $200 \mathrm{IU} / \mathrm{kg}$ every 6 hours until resolution of lesions. Doses of PC concentrate in patients with DVT ranged from $40 \mathrm{IU} / \mathrm{kg}$ every 6 to 18 hours to $100 \mathrm{IU} / \mathrm{kg}$ once a day for 2 weeks. Patients with coumarin-induced skin necrosis were successfully treated with PC concentrate at doses of $80 \mathrm{IU} / \mathrm{kg}$ per day for several days and overlapping to the initiation of OAC. ${ }^{18,20-21,44,68,69}$

In general, patients with acute $\mathrm{PF}$ and/or DIC receiving PC concentrates in the early stage of the disease showed a much more favorable outcome than patients receiving PC concentrates after several days. However, early administration of PC concentrates in patients with intrauterine, intracerebral, or intraocular hemorrhage or infarction did not prevent longterm neurological complications or visual impairment. Few cases are reported where treatment with FFP or PC concentrate was too late to save the patient's life. ${ }^{23,41,52,54,56,63-64}$

\section{General recommendations}

No well-defined general dose guidelines are available for the treatment of symptomatic patients with severe congenital PC deficiency. However, available information from small case series and case reports suggests that the use of FFP or PC concentrates may positively influence long-term outcomes, especially when administered early in the disease. Based on this information, several recommendations have been published recently. The American College of Chest Physicians (ACCP) guidelines for antithrombotic therapy in symptomatic neonates and children recommend treatment with either 10 to $20 \mathrm{~mL} / \mathrm{kg}$ FFP every 12 hours or PC concentrates at 20 to $60 \mathrm{IU} / \mathrm{kg}$ until resolution of clinical lesions. ${ }^{70}$ Goldenberg and Manco-Johnson recommend a higher and more frequent dosage of PC concentrates consisting of an initial bolus of
$100 \mathrm{U} / \mathrm{kg}$ followed by $50 \mathrm{U} / \mathrm{kg}$ every 6 hours or administration of 10 to $15 \mathrm{~mL} / \mathrm{kg}$ of FFP every 8 to 12 hours until PC concentrate is made available. ${ }^{71}$ Knoebl et al suggest the administration of PC concentrate as an initial intravenous dose of 60 to $80 \mathrm{U} / \mathrm{kg}$ followed by injections every 6 hours, especially during the acute phase. ${ }^{36}$ Further dosage should be planned on an individual basis aiming at a PC activity of $100 \%(=100 \mathrm{U} / \mathrm{dL})$ or a trough level of about $50 \mathrm{U} / \mathrm{dL}$. The measurement of plasma PC activity before and after injection of PC is recommended in order to assess recovery and half-life, as both may be significantly reduced due to acute thrombotic events. Continuous infusions of $\mathrm{PC}$ concentrate seem to be efficient without loss of activity of PC. White et al recommend administration of a testing dose of 10 IU $/ \mathrm{kg}$ of PC concentrate, followed by a bolus dose of 100 $\mathrm{IU} / \mathrm{kg}$, and a continuous infusion of $10 \mathrm{U} / \mathrm{kg} / \mathrm{h}$, adjusted to the measured PC activity and recovery. ${ }^{72}$ Alternatively, subcutaneous administration of PC concentrate has also been described, especially for long-term treatment. In patients with coumarin-induced skin necrosis, the administration of heparin in therapeutic doses concomitant with intravenous PC concentrates is recommended. ${ }^{71}$

\section{Prophylactic use}

The goal of prophylactic administration of $\mathrm{PC}$ concentrates in patients with severe PC deficiency is to prevent relapse of acute disease, clinical manifestation during surgical procedures or pregnancy, and in the initial phase of OAC therapy. ${ }^{14,18,20,23,33,40-42,44-47,49-52,56-58,60-63,68,75}$

Prophylactic treatment is initiated after stabilization of clinical symptoms to allow an outpatient management (Table 1). In the patients reported, PC concentrate was individually reduced in dose and frequency from the therapeutic to a prophylactic level. Dose regimens of 24 to $90 \mathrm{IU} / \mathrm{kg}$ once a day, 250 to $350 \mathrm{IU} / \mathrm{kg}$ every other day, or $90 \mathrm{IU} / \mathrm{kg}$ three times a week were reported. Trough levels of PC above 15 to $25 \%$ as well as PC plasma level of 40 to $50 \%$ are thought to be sufficient to prevent relapse of PF or breakthrough skin necrosis. As an alternative to the intravenous route, several cases of subcutaneous administration of PC concentrate have been reported. ${ }^{40,45-46,56,61}$ Subcutaneous doses of PC concentrate range between 66 to $100 \mathrm{IU} / \mathrm{kg}$ once a day, $350 \mathrm{IU} / \mathrm{kg}$ every other day, and $250 \mathrm{IU} / \mathrm{kg}$ every third day. Duration of subcutaneous PC concentrate administration varies between 1 to 48 hours. For continuous subcutaneous PC infusion by pump, doses ranging from 192 to $350 \mathrm{IU} / \mathrm{kg} / 48$ hours are reported. Half-life of PC following intravenous and subcutaneous administration is 6 and 16 hours, respectively. ${ }^{57}$ 
Subcutaneous application is shown to be a reasonable alternative to the intravenous route, especially in the pediatric population as well as in long-term prophylactic treatment. However, long-term subcutaneous application can lead to subcutaneous fibrosis. ${ }^{35}$

Long-term OAC for prophylaxis was attempted at least once in almost all patients reported (Table 1). The switch from acute treatment with FFP or PC concentrate, at doses of 40 to $80 \mathrm{IU} / \mathrm{kg} / \mathrm{d}$ or 200 to $500 \mathrm{IU} /$ dose, to OAC was performed as early as after 5 days and up to several weeks or even years of PC substitution. ${ }^{73}$ During long-term treatment with OAC as single agent, breakthrough PF and/or thrombotic complications were commonly seen in patients with severe PC deficiency. A successful combination of OAC with a target International Normalized Ratio (INR) of 1.5 to 2.5 and administration of $\mathrm{PC}$ concentrate at doses of 30 to $50 \mathrm{IU} / \mathrm{kg}$ every 1 to 3 days was reported in 8 patients. $^{71}$

\section{General recommendations}

As above, no well-defined general dose guidelines are available for the prophylactic treatment of patients with severe congenital PC deficiency. In the ACCP guidelines for antithrombotic therapy in neonates and children, long-term treatment with PC concentrate replacement, next to treatment with long-term OAC, low-molecular-weight heparin, or liver transplantation is recommended. Administration of PC concentrate overlapping initiation of OAC, until an INR of 2.5 to 4.5 is achieved, has been suggested. ${ }^{68,72-74}$ Heparin is thought to overcome the risk of coumarin-induced skin necrosis in the initial phase of OAC but no data are available to demonstrate this evidence.

For surgical interventions or invasive procedures, discontinuation of OAC and commencement of bridging using PC concentrate with an initial bolus of $100 \mathrm{U} / \mathrm{kg}$ followed by a maintenance dose of 30 to $50 \mathrm{IU} / \mathrm{kg}$ every 12 to 24 hours is recommended. ${ }^{71}$

\section{Conclusions}

Severe congenital PC deficiency is a serious disease, which usually becomes evident in the neonatal period with potentially lethal thrombotic manifestations. Early substitution of PC is crucial to stabilize consumption coagulopathy and allow resolution and healing of lesions. While the current source of available information does not allow general dose recommendations, data from case series and case reports suggest that purified human PC concentrates provide an adequate, safe, and efficient substitution of PC in acute situations as well as for prophylactic use in patients with severe congenital PC deficiency.

\section{Disclosures}

The authors report no conflicts of interest in this work.

\section{References}

1. Andrew M, Paes B, Milner R, et al. Development of the human coagulation system in the full-term infant. Blood. 1987;70:165-172.

2. Reitsma PH, Bernardi F, Doig RG, et al. Protein C deficiency: a database of mutations, 1995 update. On behalf of subcommittee on plasma coagulation inhibitors of the SSC of the ISTH. Thromb Haemost. 1995;73:876-879.

3. Marlar RA, Mastovich S. Hereditary protein C deficiency: a review of the genetics, clinical presentation, diagnosis and treatment. Blood Coagul Fibrinolysis. 1990;1:319-330.

4. Albisetti M, Andrew M, Monagle P. Hemostatic abnormalities. In: Werner E, DeAlarcon P, editors. Neonatal Hematology. New York, NY: Cambridge University Press; 2005:310-348.

5. Branson H, Katz J, Marble R, Griffin JH. Inherited protein C deficiency and coumarin responsive chronic relapsing purpura fulminans syndrome in a neonate. Lancet. 1983;2:1165-1186.

6. Marciniak E, Wilson HD, Marlar RA. Neonatal purpura fulminans: a genetic disorder related to the absence of protein C in blood. Blood. 1985;65:15-20.

7. Sills RH, Hombert JR, Montgomery RR, Marlar RA. Clinical course and therapy of an infant with severe homozygous protein $\mathrm{C}$ deficiency. Blood. 1983;62:310.

8. Estelles A, Garcia-Plaza I, Dasi A, et al. Severe inherited "homozygous" protein C deficiency in a newborn infant. Thromb Haemost. 1984;52:53

9. Seligsohn U, Berger A, Abend M, et al. Homozygous protein C deficiency manifested by massive venous thrombosis in the newborn. N Engl J Med. 1984;310:559.

10. Sills RH, Marlar RA, Montgomery RR, Deshpande GN, Humbert JR. Severe homozygous protein C deficiency. J Pediatr. 1984;105(3): 409-413.

11. Marlar RA, Sills RH, Montgomery RR. Protein C in commercial factor IX concentrates and its use in the treatment of "homozygous" protein C deficiency [abstract]. Blood. 1983;62:303.

12. Marlar RA, Sills RH, Groncy PK, Montgomery RR, Madden RM. Protein $C$ survival during replacement therapy in homozygous protein $\mathrm{C}$ deficiency. Am J Hematol. 1992;41(1):24-31.

13. Marlar RA, Montgomery RR, Broekmans AW. Diagnosis and treatment of homozygous protein $\mathrm{C}$ deficiency. Report of the working party on homozygous protein $\mathrm{C}$ deficiency of the subcommittee in protein $\mathrm{C}$ and protein S, International Committee on Thrombosis and Haemostasis. J Pediatr. 1989;114:528-534.

14. Dreyfus M, Magny JF, Bridey F, et al. Treatment of homozygous protein $\mathrm{C}$ deficiency and neonatal purpura fulminans with a purified protein C concentate. N Engl J Med. 1991;325(22):1565-1568.

15. Adcock DM, Brozna J, Marlar RA. Proposed classification and pathologic mechanisms of purpura fulminans and skin necrosis. Semin Thromb Hemost. 1990;16:333-340.

16. Wehinger H, Geiger E, Freudenberg V, Schürmann J, Alexandrakis E, Witt I. Severe hereditary protein $C$ deficiency in a newborn infant with fulminant purpura - sucessful treatment with phenprocoumon. Klin Pädiatr. 1985;197(2):116-120.

17. Gatti L, Carnelli V, Rusconi R, Moia M. Heparin-induced thrombocytopenia and warfarin-induced skin necrosis in a child with severe protein $\mathrm{C}$ deficiency: successful treatment with dermatan sulfate and protein C concentrate. J Thromb Haemost. 2003;1(2):387-388.

18. Zimbelman J, Lefkowitz J, Schaeffer C, et al. Unusual complication of warfarin therapy: skin necrosis and priapism. J Pediatr. 2000;137: 266-268.

19. Monagle P, Andrew M, Halton J, et al. Homozygous protein c deficiency: description of a new mutation and successful treatment with low molecular weight heparin. Thromb Haemost. 1998;79:756-761. 
20. Alhenc-Gelas M, Emmerich J, Gandrille S, et al. Protein C infusion in a patient with inherited protein $\mathrm{C}$ deficiency caused by two missense mutations: Arg178 to Gln and Arg1 to His. Blood Coagul Fibrinolysis. 1995;6:35-41.

21. Conard J, Bauer KA, Gruber A, et al. Normalization of markers of coagulation activation with a purified protein $\mathrm{C}$ concentrate in adults with homozygous protein C deficiency. Blood. 1993;82(4):1159-1164.

22. Peters C, Casella JP, Marlar RA, Montgomery RR, Zinkham WH. Homozygous protein $\mathrm{C}$ deficiency: observations on the nature of the molecular abnormality and the effectiveness of warfarin therapy. Pediatrics. 1988;81:272-276.

23. Dreyfus M, Masterson M, David M, et al. Replacement therapy with a monoclonal antibody purified protein $\mathrm{C}$ concentrate in newborns with severe congenital protein C deficiency. Semin Thromb Hemost 1995;21(4):371-381.

24. Kernoff PB, Durrant IJ, Rizza CR, Wright FW. Severe allergic pulmonary oedema after plasma transfusion. Br J Haematol. 1972;23: 777-781.

25. Burman D, Hodson AK, Wood CB, Brueton NF. Acute anaphylaxis, pulmonary oedema, and intravascular haemolysis due to cryoprecipitate. Arch Dis Child. 1973;48:483-485.

26. Reese EP, Mc Culouzgh JJ, Craddock PR. An adverse pulmonary reaction to cryoprecipitate in a haemophiliac. Transfusion. 1975;15: 583-588.

27. Wada H, Deguch K, Shirakawa S, Suzuki K. Successful treatment of deep vein thrombosis in homozygous protein $\mathrm{C}$ deficiency with activated protein C. Am J Hematol. 1993;44(3):218-219.

28. Bernard GR, Vincent JL, Laterre PF, et al. Efficacy and safety of recombinant human activated protein $\mathrm{C}$ for severe sepsis. $N$ Engl J Med. 2001;344:699-709.

29. Manco-Johnson MJ, Knapp-Clevenger R. Activated protein C concentrate reverses purpura fulminans in severe genetic protein $\mathrm{C}$ deficiency. J Pediatr Hematol Oncol. 2004;26:25-27.

30. Rosenzweig N, Strauss T, Rubinstein M, Paret G, Kenet G. Activated protein $\mathrm{C}$ concentrate treatment for skin necrosis under warfarin treatment in severe genetic protein $\mathrm{C}$ deficiency combined with prothrombin mutation and factor V Leiden. Thromb Haemost. 2009;101:405-407.

31. Nadel S, Goldstein B, Williams MD, et al. Drotrecogin alfa (activated) in children with severe sepsis: a multicentre phase III randomised controlled trial. Lancet. 2007;369:836-843.

32. Casella JF, Lewis JH, Bontempo FA, Zitelli BJ, Markel H, Starzl TE. Successful treatment of homozygous protein $\mathrm{C}$ deficiency by hepatic transplantation. Lancet. 1988;27:435-437.

33. Angelis M, Pegelow CH, Khan FA, Verzaro R, Tzakis AG. En bloc heterotopic auxiliary liver and bilateral renal transplant in a patient with homozygous protein C deficiency. J Pediatr. 2001;138:120-122.

34. Lee MJ, Kim KM, Kim JS, Kim YJ, Lee YJ, Ghim TT. Long-term survival of a child with homozygous protein $\mathrm{C}$ deficiency successfully treated with living donor liver transplantation. Pediatr Transplant 2009:13:251-254.

35. Monagle P, Ignjatovic V, Newall F, et al. Multi modal management of purpura fulminans due to homozygous protein C deficiency. J Thromb Haemost. 2005;3 Suppl 1:PO124.

36. Knoebl P. Human protein $\mathrm{C}$ concentrates for replacement therapy in congenital and acquired protein C deficiency. Drugs Today. 2008;44(6):429-441.

37. Katsuura Y, Aoki K, Tanabe H, Kiyoki M, Funatsu A. Characteristic effects of activated human protein $\mathrm{C}$ on tissue thromboplastin-induced disseminated intravascular coagulation in rabbits. Thromb Res 1994;76:353-362.

38. Nakayama T, Matsushita T, Hidano H, et al. A case of purpura fulminans is caused by homozygous delta8857 mutation (protein C-Nagoya) and successfully treated with activated protein $\mathrm{C}$ concentrate. $\mathrm{Br} \mathrm{J}$ Haematol. 2000;110:727-730.

39. Kumagai K, Nishiwaki K, Sato K, et al. Perioperative management of a patient with purpura fulminans syndrome due to protein $\mathrm{C}$ deficiency. Can J Anesth. 2001;48(11):1070-1074.
40. Olivieri M, Bidlingmaier C, Behnisch W, et al. Management of subcutaneous protein $\mathrm{C}$ substitution in children with severe protein $\mathrm{C}$ deficiency. J Thromb Haemost. 2009; 7 Suppl 2:PP-WE-453.

41. Tcheng WY, Dovat S, Gurel Z, Donkin J, Wong WY. Severe congenital protein $\mathrm{C}$ deficiency: description of a new mutation an prophylactic protein $\mathrm{C}$ therapy and in vivo pharmacokinetics. J Pediatr Hematol Oncol. 2008;30:166-171.

42. Dreyfus M, Ladouzi A, Chambost H, et al. Treatment of inherited protein $\mathrm{C}$ deficiency by replacement therapy with the French purified plasma-derived protein C concentrate (PROTEXEL ${ }^{\circledR}$ ). Vox Sanguinis. 2007;93:233-240.

43. Hertfelder HJ, Pavlova A, Kamil D, et al. Postnatal management of a severely protein $\mathrm{C}$ deficient newborn by protein $\mathrm{C}$ concentrate substitution. Hämostaseologie. 2007;27:A21.

44. Beneke H, Langer C, Struve S, Griesshammer M, Oldenburg J, Grünewald M. Pregnancy Of A Libanese Woman With Homozygous Protein C Deficiency. J Thromb Haemost. 2005;3 Suppl 1:P1324.

45. Fernandez-Burriel M. Severe clinical presentation of protein C deficiency in a type I/II compound heterozygote newborn. Thromb Haemost. 2005;94:216-218.

46. Mathias M, Khair K, Burgess C, Liesner R. Subcutaneous administration of protein C concentrate. Pediatr Hematol Oncol. 2004;21:551-556.

47. Salonvaara M, Kuismanen K, Mononen T, Riikonen P. Diagnosis and treatment of a newborn with homozygous protein $\mathrm{C}$ deficiency. Acta Paediatr. 2004;93:137-139.

48. Guérin V, Ryman A, Pedespan JM, Freyburger G, Calvora R. Oral anticoagulant therapy initiation in a severely protein $\mathrm{C}$ deficient infant: use of human protein C concentrate [abstract]. Blood. 2003;102(11):4197.

49. Abu-Amero KK, Al-Hamed MH, Al-Batniji FS. Homozygous protein C deficiency with purpura fulminans: report of a new case and a description of a novel mutation. Blood Coagul Fibrinolysis. 2003;14:303-306.

50. Hertfelder HJ, Kornbrust AM, Effenberger W, Hanfland P, Lentze MJ. Pharmacokinetics of Protein $\mathrm{C}$ concentrate Ceprotin ${ }^{\mathrm{TM}}$ in treatment of a child with severe homozygous protein $\mathrm{C}$ deficiency [abstract]. 46th Annual Meeting Society for Thrombosis and Hemostasis Research; Germany, February 20-23, 2002.

51. Hertfelder HJ, Kornbrust AM, Pannier-Fischer M, Rabe E, Hanfland P, Lentze MJ. Treatment of thrombotic complications and prophylactic use of protein $\mathrm{C}$ concentrate in two homozygous protein $\mathrm{C}$ deficient patients during surgery. J Thromb Haemost. 2003; Suppl:P1022.

52. Monagle P, Newall F, Ignjatovic V, Sarkaar S, Campbell J, Savoia H. Homozygous protein $\mathrm{C}$ deficiency: subcutaneous protein $\mathrm{C}$ replacement is effective as salvage or maintenance therapy. Blood. 2002;11:267a.

53. Steinkamp M, Geva A, Joffe S, Lapp CN, Neufeld EJ. Chronic disseminated intravascular coagulation and childhood onset skin necrosis resulting from homozygosity for a protein $\mathrm{C}$ G1a domain mutation Arg15Trp. J Pediatr Hematol Oncol. 2002;24:685-688.

54. Churchill AJ, Galagher MJ, Bradbury JA. Clinical manifestations of protein C defiency: a spectrum within one family. Br J Ophthalmol. 2001;85:238-248.

55. Wermes C, Bergmann F, Reller B, Sykora KW. Severe protein C deficiency and aseptic osteonecrosis of the hip joint: a case report. Eur $J$ Pediatr. 1999;158 Suppl 3:159-161.

56. Sanz-Rodriguez C, Gil-Fernandez JJ, Zapater P, et al. Long-term management of homozygous protein $\mathrm{C}$ deficiency: replacement therapy with subcutaneous purified protein C concentrate. Thromb Haemost. 1999;81(6):887-890.

57. Minford AMB, Parapia LA, David M, Gomez N, Sanz-Rodriguez C, Bond M. Treatment of homozygous protein $\mathrm{C}$ deficiency with subcutaneous protein $\mathrm{C}$ concentrate - experience from four centers [abstract]. XVII Congress of the ISTH; Washington DC, USA, August 14-21,1999:0898.

58. Hattenbach LO, Beeg T, Kreuz W, Zubcov A. Ophthalmic manifestation of congenital protein C deficiency. J AAPOS. 1999;3(3):188-190.

59. Paret G, Barzilai A, Barzilay Z. Purpura fulminans skin lesions in a newborn with complete protein C deficiency. J Pediatr. 1998; 132(3 Pt 1):558. 
60. Richards EM, Makris M, Preston FE. The successful use of protein C concentrate during pregnancy in a patient with type 1 protein $\mathrm{C}$ deficiency, previous thrombosis and recurrent fetal loss. Br J Haematol. 1997;98(3):660-661.

61. Minford AM, Parapia LA, Stainforht C, Lee D. Treatment of homozygous protein $\mathrm{C}$ deficiency with subcutaneous protein $\mathrm{C}$ concentrate. Br J Haematol. 1996;93(1):215-216.

62. Muller FM, Ehrenthal W, Hafner G, Schranz D. Purpura fulminans in severe congenital protein $\mathrm{C}$ deficiency: monitoring of treatment with protein C concentrate. Eur J Pediatr. 1996;155(1):20-25.

63. Baliga V, Thwaites R, Tillyer MI, Minford A, Parapia L, Allgrove J. Homozygous protein $\mathrm{C}$ deficiency - management with protein $\mathrm{C}$ concentrate. Eur J Pediatr. 1995;154(7):534-538.

64. Cassels-Brown A, Minford AMB, Chatfield SL, Bradbury JA. Ophthalmic manifestations of neonatal protein $\mathrm{C}$ defieiency. Br J Ophthalmol. 1994;78:486-487.

65. Christoph JE, Heimig R. Homozygoter Protein C Mangel Diagnostische und therapeutische Aspekte. Monatsschrift Kinderheilkunde. 1994;142(8 Suppl 1):P414.

66. De Stefano V, Mastrangelo S, Schwarz HP, et al. Replacement therapy with a purified protein $\mathrm{C}$ concentrate during initiation of oral anticoagulation in severe protein C congenital deficiency. Thromb Haemost. 1993;70(2):247-249.

67. Auberger K. Evaluation of a new protein-C concentrate and comparison of protein-C assays in a child with congenital protein-C deficiency. Ann Hematol. 1992;64(3):146-151.
68. Vukovich T, Auberger K, Weil J, Engelmann H, Knöbl P, Hadorn HB. Replacement therapy for a homozygous protein $\mathrm{C}$ deficiency-state using a concentrate of human protein C and S. Br J Haematol. 1988;70(4):435-440.

69. Conard J, Horellou MH, van Dreden P, et al. Homozygous protein C deficiency with late onset and recurrent coumarin-induced skin necrosis. Lancet. 1992;399:743-744.

70. Monagle P, Chalmers E, Chan A, et al. Antithrombotic therapy in neonates and children. CHEST. 2008;133:887S-968S

71. Goldenberg A, Manco-Johnson MJ. Protein C deficiency. Haemophilia. 2008;14:1214-1221.

72. White B, Livingstone W, Murphy C, Hodgson A, Rafferty M, Smith OP. An open-label study of the role of adjuvant hemostatic support with protein $\mathrm{C}$ replacement therapy in purpura fulminans-associated meningococcemia. Blood. 2000;96:3719-3724.

73. Hartmann KR, Manco-Johnson M, Rawlings JS, Bower DJ, Marlar RA. Homozygous protein $\mathrm{C}$ deficiency: early treatment with warfarin. Am J Pediatr Hematol Oncol. 1989;11:395-401.

74. Marlar RA, Montgomery RR, Broekmans AW. Diagnosis and treatment of homozygous protein $\mathrm{C}$ deficiency. Report of the working party on homozygous protein $\mathrm{C}$ deficiency of the ISTH-Subcommittee on protein $\mathrm{C}$ and protein $\mathrm{S}$, International Committee on Thrombosis and Haemostasis. Thromb Haemost. 1989;61(3):529-531.

75. Imberti D, Pierfranceschi MG. Successful protein C concentrate administration during initiation of oral anticoagulation in adult patients with severe congenital protein $\mathrm{C}$ deficiency: report of two cases. Pathophysiol Haemost Thromb. 2008;36:53-57.
Biologics: Targets \& Therapy

\section{Publish your work in this journal}

Biologics: Targets \& Therapy is an international, peer-reviewed journal focusing on the patho-physiological rationale for and clinical application of Biologic agents in the management of autoimmune diseases, cancers or other pathologies where a molecular target can be identified. This journal is indexed on PubMed Central, CAS,

\section{Dovepress}

EMBase, Scopus and the Elsevier Bibliographic databases. The manuscript management system is completely online and includes a very quick and fair peer-review system, which is all easy to use. Visit http://www.dovepress.com/testimonials.php to read real quotes from published authors. 